\title{
Herbs that heal: Floristic boon to the natural healthcare system
}

\author{
Tamanna Malik*, V. K. Madan* and Ram Prakash** \\ Department of Chemistry, Chaudhary Charan Singh Haryana Agricultural University, Hisar-125004, Haryana, India \\ *MAP Section, Department of Genetics and Plant Breeding, Chaudhary Charan Singh Haryana Agricultural University, Hisar-125004, Haryana, India \\ **Department of Soil Science, Chaudhary Charan Singh Haryana Agricultural University, Hisar-125004, Haryana, India
}

\section{Article Info \\ Article history \\ Received 10 September 2020 \\ Revised 2 November 2020 \\ Accepted 3 November 2020 \\ Published online 30 December 2020}

\section{Keywords \\ Antioxidant \\ Herbs}

Phytochemical

Antimicrobial

\begin{abstract}
Over the past decade, herbal medicines have become a topic of global importance, making an impact on both world health and international trade. Among prehistoric civilizations, India has been known to be loaded depository of medicinal herbs. Medicinal plants continue to play a vital role in the healthcare system of large proportions of the world's population. Different herbs are obtained from different parts of the plant, i.e., roots, leaves, barks, seeds or flowers. The consumption of fruits and vegetables has been found to be associated with lowering of these diseases as they contain a large amount of phenolics compounds, antioxidants and flavonoids. Phenolics occur naturally in plants and are present in fruits, vegetables, leaves, nuts, seeds and flowers; therefore, they are present in the human diet, but are also used in some medicinal preparations. Medicinal plants have been acknowledged as an impending source of natural antioxidants throughout the world. The medicinal value of plant lies in chemical substances that produce a definite physiological action on human body. The most essential bioactive constituents of these herbs include alkaloids, tannins, flavonoids and phenolic compounds. Taking into account of this fact, hereby the present study was conducted on Triphala and its fruit constituents, viz, Amla (Phyllanthus emblica Linn.), Bahera (Terminalia belerica Roxb.) and Harad (Terminalia chebula Retz.) in order to obtain these natural therapeutic agents to appear as a floristic boon to natural health care system. The results showed that aqueous fruit extracts of E. officinalis, T. chebula and T. belerica could serve as a potential antioxidant and antimicrobial constituents. This methodical exploration of these Indian medicinal herbs proved crucial for getting to know about their chemical constituents and functionality in Ayurvedic medicine, and contributes to the search for natural sources of strong antioxidants.
\end{abstract}

\section{Introduction}

The herbal medicinal practice dates back to the very earliest periods of known human history. Several evidences are there for proving that the herbs obtained from medicinal plants have been used for the cure of various diseases and for healing and boosting the physical and mental health in almost all the ancient civilizations, the Indian, the Egyptians, the Chinese and even the Greek and Roman civilizations. The mystical and supernatural power of healing along with main stay of medicine is credited only to the plants. In India, a large number of records indicate that the medicinal herbs had been used for the treatment of various ailments since ancient times. Herbs play a significant role, especially in modern times, when the damaging effect of food processing, pollution, cigarette smoking, stress and overuse of medicines has assumed startling proportions. The growing interest in herbs is a part of the movement towards change in life style. This movement is based on the belief that plants have a vast potential for their use as an alternate and curative medicines.

Corresponding author: Dr. Tamanna Malik

Department of Chemistry, Chaudhary Charan Singh Haryana Agricultural University, Hisar-125004, Haryana, India E-mail: maliktamanna1996@gmail.com

Tel.: +91-9717652057

Copyright (c) 2020 Ukaaz Publications. All rights reserved.

Email: ukaaz@yahoo.com; Website: www.ukaazpublications.com
According to Temple (2000) and Willett (2002), plants and herbs have been used an important contributor to the quality of human life for thousands of years. They provide abundant natural antioxidants which are virtually important for human health. Oxidants and antioxidants in humans are maintained in balance in a normal physiological state. However, the overproduction of oxidants in certain conditions may cause oxidative stress, leading to oxidative damage to biomolecules and cells. Antioxidants are very important for human health. Natural antioxidants or other compounds such as vitamins, minerals or proteins can neutralize free radicals. Yanai et al. (2008) stated that antioxidant supplementation is recommended to provide cellular protection from the deleterious effects of excessive reactive oxygen species concentration. The need for antioxidants becomes even more critical with increased exposure to free radicals. Pollution, cigarette smoking, drugs, illness, stress, and even exercise can increase free radical exposure (Ablise et al., 2011). The traditional system of herbal medicinal practice out-competes the use of synthetic drugs due to the fact of natural origination, cost effectiveness and least side effects. In contrast, synthetic drugs exhibit toxic and mutagenic effects than natural drugs (Vijayabaskar and Shiyamala, 2012). These attributes bring extensive use of these herbal medicines since thousands of years in developing and developed countries. Further, synthetic antioxidants such as butylated hydroxyl anisole (BHA) 
and butylated hydroxyl toluene (BHT) have restricted use in food because of their carcinogenic properties (Ito et al., 1985). As a result of herbal medicinal practice, several fresh and non-drug substances were innovated. So, it is prime important to formulate novel medicines by eradicating constraints in the herbal medicinal practices.

The search for new cures has always been dependent on the traditional knowledge of medicinal plants. In spite of the introduction of modern high tech drug discovery and screening techniques, traditional knowledge systems have given evidences to the discovery of valuable drugs (Buenz et al., 2004). Due to local availability, easy consumption as raw or simple medicinal preparations and in-expensiveness of conventional medicinal plants, the traditional medicinal practices are forming an integral part of complementary medicine. According to WHO, about $80 \%$ of global population relies chiefly on plant based conventional medicine for their primary healthcare need. Despite the fact, toxicity of plant derived medicines has not been known as it is generally assumed that medicines obtained from plants are way safer than synthetic drugs. The plant kingdom is a potent source of drugs and nowadays, it has been observed that increasing awareness about the significance of medicinal plants has led to an increase in the global market (Hammer et al., 1999). Plants with traditional pharmacological profile are being screened. Plants are an exceptional source of natural antioxidants and antimicrobials, which may act as potent drugs in modern biomedicine (Voon et al., 2012). Various medicinal plants are being explored globally for their antioxidant, anticancer, antimicrobial properties and therapeutic potential (Baba and Malik, 2015). Numerous plants are known to have significant amount of free radical scavengers such as phenols, flavonoids, terpenoids, saponins and glycosides. Owing to the presence of natural antioxidants in plants, these metabolites are known to relieve oxidative stress. Oxidative environment in the living organisms contains superoxide, hydroxyl radical, nitric oxide and peroxynitrite. These free radicals are responsible for a number of diseases such as cancer, neurodegeneration and other diseases resulting from inflammation. Apart from the free radicals in the form of enzymes present in human body so as to counteract the effects of free radical by innate defence mechanisms induced by the body itself, plants secondary metabolites, namely; phenols, flavonoids, tannins play an important role as plant antioxidants (natural origin) in providing defence against free radicals producing oxidative stress (Devasagayam and Sainis, 2002; Govindarajan, Vijayakumar and Pushpangadan, 2005; Park and Pezzutto, 2002).

It is quite a good fortune that diversity of India comprises of a wide variety of flora consisting of several traditionally used medicinal plants, which form an integral part of Indian Ayurveda. Ayurveda is a time tested medicinal system developed by Dhanvantris of ancient India who have continuously screened the plants of India for their therapeutic effects in an empherical manner. The present multinational companies are also screening these same plants but in scientific manner to obtain active molecules for certain target receptors. These medicinal plants have various naturally occurring non-toxic antioxidants. Therefore, efforts to acquire extensive knowledge regarding the power of natural antioxidants in the form plant metabolites are increasing to tap their potential or efficacies. In contrast, synthetic drugs exhibit toxic and mutagenic effects than natural drugs (Vijayabaskar and Shiyamala 2012).

Keeping in mind the adverse effects of synthetic antioxidants, researchers have channelled their interest in isolating natural antioxidants (Kuo et al., 2005) which are very effective to control the oxidative stress and, hence prevent the initiation of disease propagation. Therefore, an alternative is the consumption of natural antioxidants from various food supplements and traditional medicines.

Natural antioxidants are usually phenolic and polyphenolic compounds (Siddique et al. 2010). Phenolic compounds had shown significant antioxidant activity (Wei and Shibamoto, 2007; Vundać et al., 2007). Polyphenols are the major compounds and are commonly found in both edible and nonedible common plants and animal products. It has multiple biological effects, including antioxidant activity (Parcheta et al., 2011). Their antioxidant activity is mainly due to their redox properties, hydrogen donors and singlet oxygen quenchers, which can play an important role in adsorbing and neutralizing free radicals, quenching singlet and triplet oxygen, or decomposing peroxides. In the present studies, we investigated the phytochemicals, nutritional parameters (proximate composition, mineral contents and phytochemical contents) and the biological activities of Amla, Bahera and Harad so as to observe their effects on natural health care system.

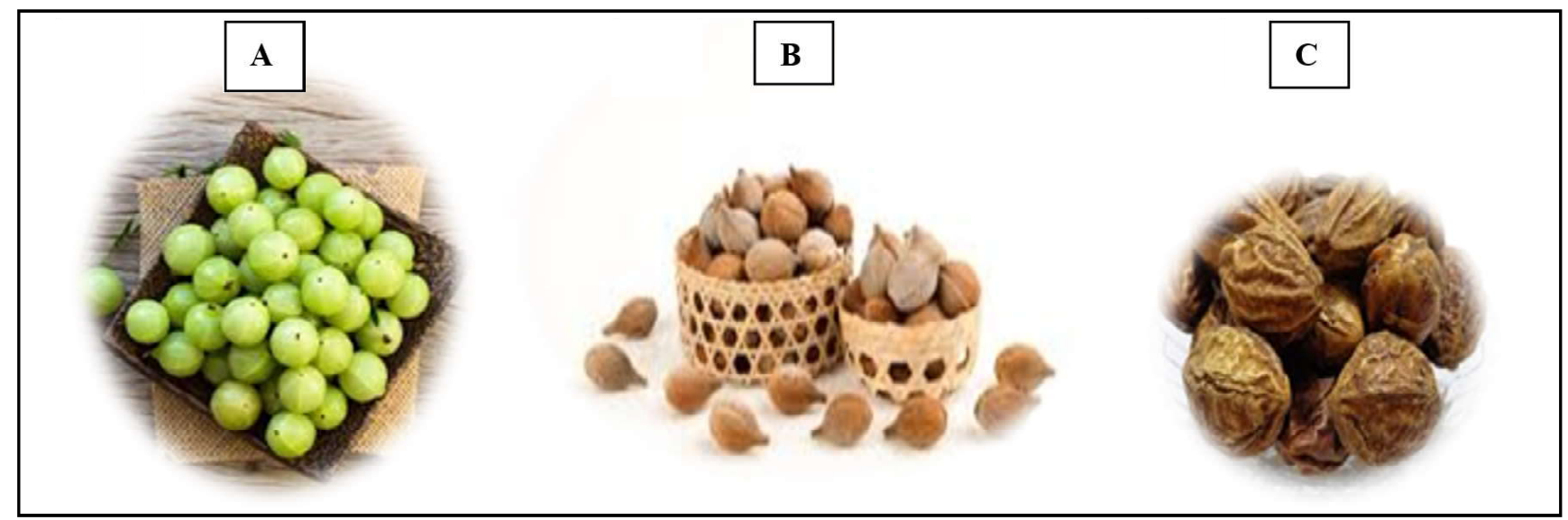

Figure 1: Medicinal herbs taken for study: A. Amla, B. Bahera, and C. Harad. 
In Indian medicinal preparation, Triphala (tri 'three'; phala 'fruits') comprises a mixture of herbal fruits: viz. E. officinalis (Syn. P. emblica), T. belerica and T. chebula. Triphala constituents are rich in antioxidants and reported to possess antimicrobial properties. Dry fruit extracts of E. officinalis, T. belerica and T. chebula were screened for the secondary metabolites presence and its antioxidant, antimicrobial activities were determined as well. The sign of biochemical properties opens up an arena to bring its effective use as a single or in combination, against different pathological conditions. These plants were selected to compare the proximate parameters and micronutrients composition. Since many of these herbal products are used orally, therefore, to know proximate and nutrient analysis of these products and raw material used therein plays a crucial role in assessing nutritional significance and health effects (Kochhar et al., 2006; Pandey et al., 2006; Taiga et al., 2008).

\section{Materials and Methods}

\subsection{Procurement of materials}

Amla, Bahera, Harad were acquired from Hisar, Haryana and Triphala powder was prepared by mixing the fruits in the ratio as Amla (3), Bahera (2) and Harad (1).

\subsection{Botanical description of research materials}

Emblica officinalis Linn. is commonly called the 'Indian gooseberry'. It belongs to the family Euphorbiaceae, and is known as Amla in Hindi, and Amalaki in Sanskrit. It is a small to medium-sized tree with a crooked trunk and spreading branches, and grayish-green bark that peels off in flakes. The fruits are depressed globose in shape, $1-2.5 \mathrm{~cm}$ in diameter, fleshy, and obscurely six-lobed, containing six trigonous seeds. They are green when unripe, and turn light yellow or brick red when mature.
Terminalia chebula Retz. is a medium to large deciduous tree growing to $30 \mathrm{~m}(98 \mathrm{ft})$ tall, with a trunk up to $1 \mathrm{~m}(3 \mathrm{ft} 3 \mathrm{in})$ in diameter. The fruit is drupe-like, $2-4.5 \mathrm{~cm}(0.79-1.77 \mathrm{in})$ long and $1.2-2.5 \mathrm{~cm}$ (0.47-0.98 in) broad, blackish, with five longitudinal ridges. The fruits are smooth ellipsoid to ovoid drupes, yellow to orange-brown in colour, with a single angled stone.

Terminalia belerica (Gaertn.) Roxb. leaves are about $15 \mathrm{~cm}$ long and crowded toward the ends of the branches. It is considered a good fodder for cattle. T. belerica seeds have an oil content of $40 \%$, whose fatty-acid methyl ester meets all of the major biodiesel requirements in the USA, Germany and European Union. The seeds are called bedda nuts.

Triphala (in Sanskrit, tri $=$ three and phala $=$ fruits) is another important Ayurvedic medicinal preparation comprising three fruits: P. emblica or E. officinalis, T. chebula, and T. bellerica. Triphala is one of the most well-studied Ayurvedic formulations, and experiments have shown it to possess antibacterial, antifungal, free radical scavenging, antioxidant, anti-inflammatory, laxative, antiarthritic, anticataleptic, properties, etc.

\section{Evaluation of phytochemical and nutritional parameters}

Proximate composition comprises of 6 parameters as moisture (\%), crude fat $(\%)$, ash (\%), crude protein $(\%)$, crude fibre (\%) and total carbohydrates (\%). In case of mineral contents, 4 minerals $(\mathrm{Fe}, \mathrm{Cu}$, $\mathrm{Zn}$ and $\mathrm{Mn}$ ) are estimated in ppm. Total phenolics and flavonoids content were evaluated in aerial parts and roots extracts of Amla, Bahera and Harad in aqueous medium and in fruit extracts of Triphala powder and its fruits constituents using various solvents (aqueous, methanol, ethanol and acetone).

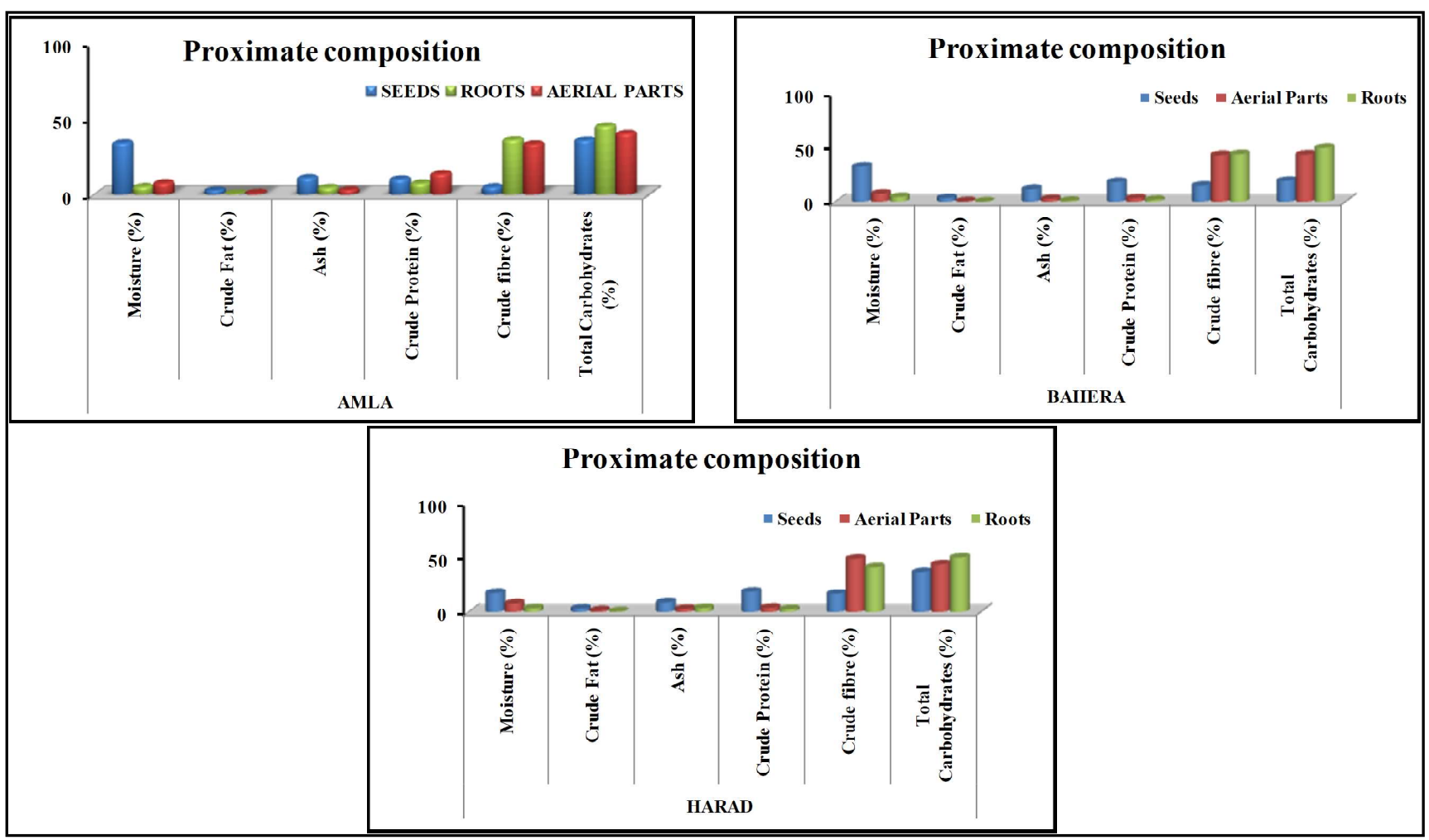

Figure 2: Proximate composition in different parts of Amla (A), Bahera (B), and Harad (C). 
Crude protein (\%), crude fibre (\%) and total carbohydrates were found maximum in Harad, followed by Bahera and Amla. The moisture content (\%) was found maximum in Amla, followed by Bahera and Harad. Overall proximate composition was found maximum in seeds, followed by aerial parts and roots of Triphala powder fruits constituents. The difference found in the proportion of proximate parameter of these medicinal plants might be attributed to the conditions on which the plant species are harvested along with environmental parameters (Nordeide et al., 1996; Kutbay and Tolga, 2001). The result of proximate analysis shows variant concentration/proportions of biochemicals and other contents.

\subsection{Minerals content analysis}

The micronutrients analysis ( $\mathrm{Fe}, \mathrm{Cu}, \mathrm{Mn}$ and $\mathrm{Zn}$ content in $\mathrm{ppm}$ ) of the medicinal plant species showed considerable variation among different micronutrients. $\mathrm{Zn}$ and $\mathrm{Mn}$ content (ppm) was found maximum in Amla, followed by Bahera and Harad. Fe content (ppm) was found maximum in Bahera, followed by Amla and Harad. Whereas, $\mathrm{Cu}$ content (ppm) was found highest in Harad, followed by Bahera and Amla. However, for some species difference or higher concentration was recorded, which may be due to prevailing environmental and soil conditions and the season when the plants were collected for analysis (Patterson, 1996; Kutbay and Tolga, 2001; Odebunmi et al., 2009).

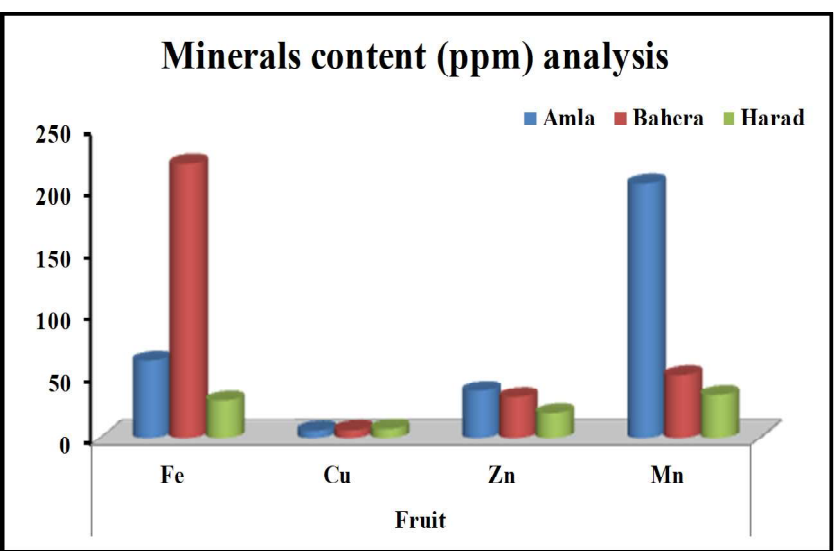

Figure 3: Minerals content analysis in different parts of Amla, Bahera and Harad.

\subsection{Phytochemical constituents (Total phenolics and total flavonoids content) analysis}

Plants extracts made with water are nutritionally more relevant, thus used for the estimation of antibacterial and antifungal activity. Extracts prepared using solvents of varying polarity were screened for their free radical scavenging and total antioxidant capacity by chemical assays. Total phenolics content was determined in order to assess their effect on the antioxidant activity of the extract. The properties of extracting solvents affected the measured total phenolics content and antioxidant activity. Extracts of all the samples, viz, T. belerica, T. chebula, E. officinalis and Triphala powder exhibited antioxidant potential and were proved to be more active. The presence of antioxidant activity in the extracts showed that these plants have the potential to be an alternate source of natural antioxidants. In the paper of Cook and Samman (1996), it was discussed that phenolics contents are very important plant constituents because of their scavenging ability due to their hydroxyl groups. Flavonols (such as quercetin, myricetin kaempherol) and flavones (e.g., apigenin, luteolin) in plant materials are closely associated with their antioxidant function mainly due to their redox properties exerted by various possible mechanisms: free-radical scavenging activity, transition-metal-chelating activity, and/or singletoxygen-quenching capacity (Shan et al., 2005; Lotito and Frei, 2006). It has been acknowledged that phenolics and flavonoids show significant antioxidant action on human and animal health and fitness. They act through scavenging or chelating process. Total phenolics content (TPC) and flavonoids contents (TFC) in aerial parts and roots in aqueous medium were estimated. Aerial parts extracts have considerable TPC and TFC as compared to roots extracts. TPC (mg GAE/g) was found maximum in Harad followed by Amla and Bahera whereas, the values for TFC were maximum in Harad followed by Bahera and Amla.

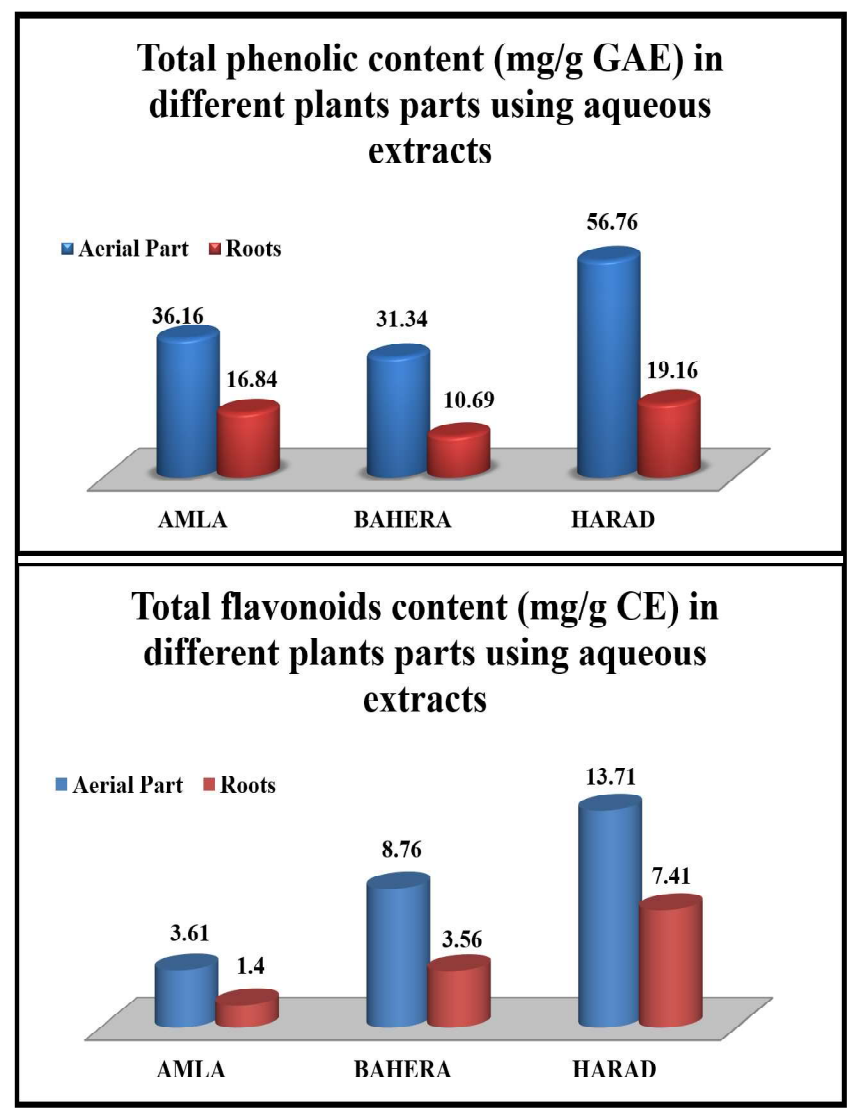

Figure 4: A. Total phenolics contents (mg GAE/g) in different plant parts using aqueous extracts. B. Total flavonoids contents $(\mathrm{mg} \mathrm{CE} / \mathrm{g})$ in different plant parts using aqueous extracts.

Total phenolics contents and flavonoids content in fruits extracts of Triphala powder and its fruits constituents using various solvents (aqueous, methanol, ethanol and acetone) were estimated in terms of $\mathrm{mg} \mathrm{GAE} / \mathrm{g}$ and $\mathrm{mg} \mathrm{CE} / \mathrm{g}$, respectively. TPC was found maximum in Amla, followed by Triphala powder, Bahera and Harad. The TFC was maximum for Bahera, followed by Triphala powder, Amla and Harad. Total phenolics were largest in aqueous extracts followed by methanol, ethanol and acetone, whereas, total flavonoids were 
largest in methanol followed by acetone, aqueous and ethanol. Solvent polarity plays a key role in increasing phenolics solubility (Wong and Kitts, 2003). Phenolic compounds such as BHT, propyl gallate, etc., are known to be effective antioxidants. Phenolic compounds have been known to act as antioxidants not only because of their ability to donate electrons also because of their stable radical intermediates which can effectively prevent the oxidation at cellular and physiological level (Chang and Lin, 2012). Extraction solvent significantly alter the antioxidant estimation, therefore, selection of extracting solvent of matching polarity is one of the most important factors in the extraction of antioxidants.

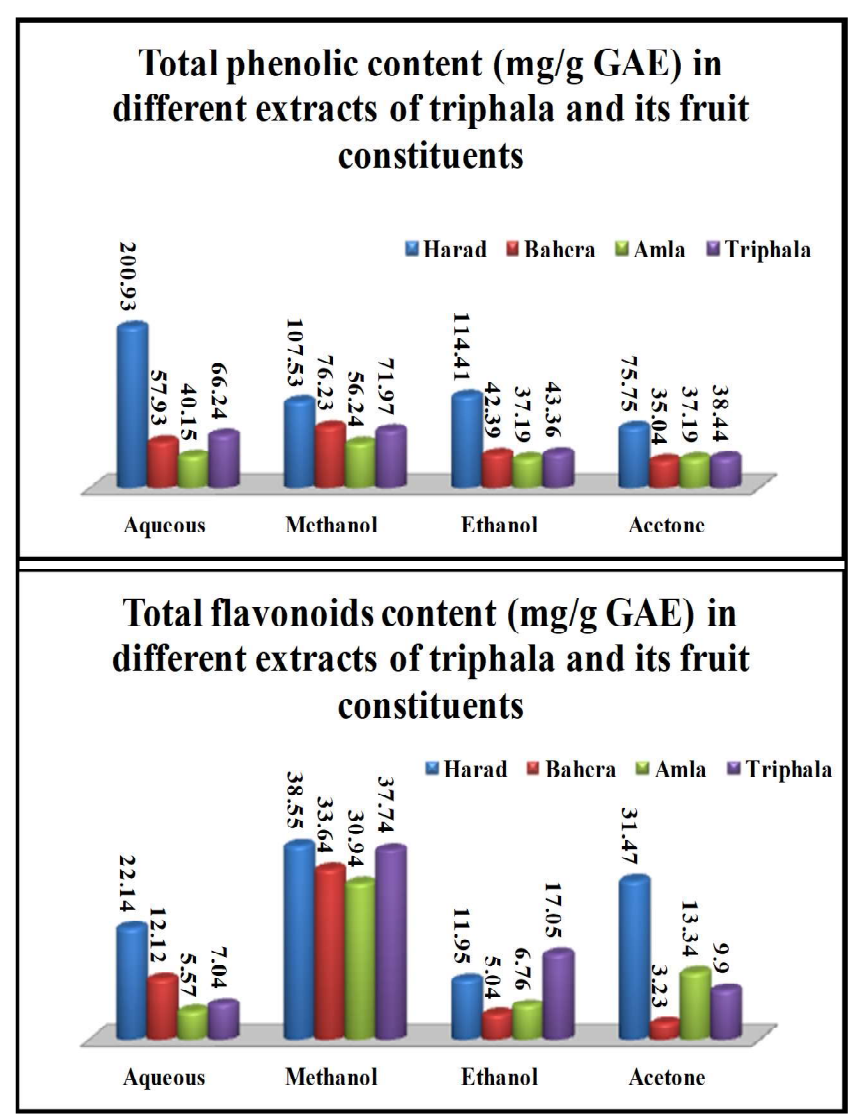

Figure 5: A. Total phenolics contents (mg GAE/g) in different extracts of Triphala and its fruit constituents. B. Total flavonoids contents (mg CE/g) in different extracts of Triphala and its fruit constituents.

Different phenolics compounds may show different antioxidant activities depending on their structure as well as synergistic or antagonistic effect of other compounds present in the extract. The selection of an appropriate solvent system is one of the most relevant steps in optimizing the recovery of total phenolics content and other antioxidant compounds from a sample (Gökmen et al., 2009). Total phenolics are often extracted in more polar solvents such as aqueous, methanol, ethanol and acetone. Wide range of total phenolics has been reported by various authors in these medicinal plant samples, which might be due to the difference in climacteric conditions, raw material composition and solvents of different concentration used for analysis (Prasad et al., 2009).
Extract Yield (g/100 g) was estimated in fruit extracts of Triphala powder and its constituents. It was maximum in Harad, followed by Triphala powder, Amla and Bahera. The extract yield for extracting solvents was highest for aqueous, followed by methanol, ethanol and acetone. The difference in the extract yield from all the samples might be due to different availability of extractable components resulting from the varied chemical composition of Triphala powder and its fruit constituents: Amla, Bahera and Harad. The amount of the antioxidant components that can be extracted is mainly affected by the vigor of the extraction procedure which probably may vary from sample to sample.

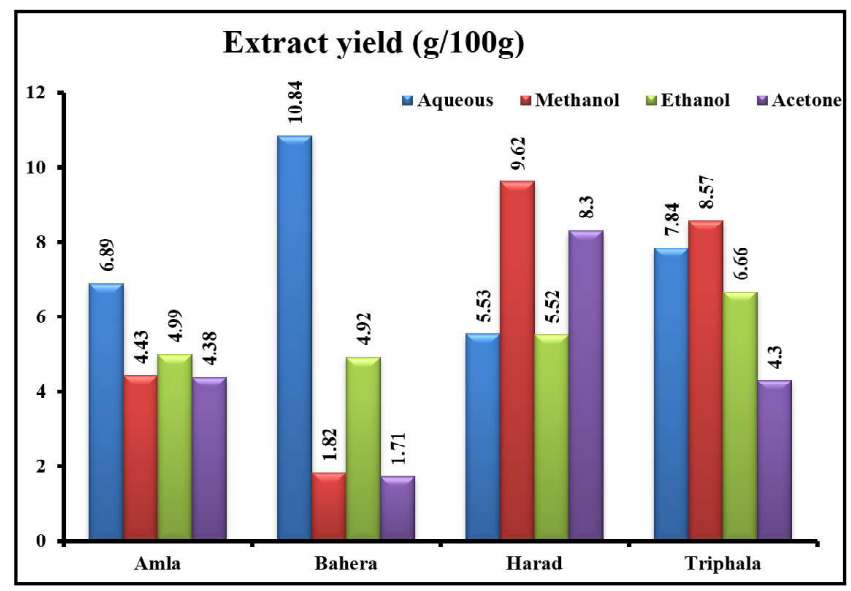

Figure 6: Extract yield (g/100 g) of different extracts of Triphala and its fruit constituents.

\section{Evaluation of total antioxidant potential of the extracts}

Antioxidant activity is expressed as $\mathrm{IC}_{50}$ value. Antioxidant activity of extract was showed with $\mathrm{IC}_{50}$ value. $\mathrm{IC}_{50}$ value of $\mathrm{DPPH}$ scavenging activities was contradiction with percentage of DPPH free radical scavenging activities. It means, the highest antioxidant activity was indicated by the lowest value of $\mathrm{IC}_{50}$. The environmental conditions (Ngamkitidechakul et al., 2010) such as sunlight condition (Ghasemzadeh et al., 2014), the maturity part of plant and different parts of plant could be a factor to different type and quantity of secondary metabolites (Wang et al., 2003; Dumas et al., 2003) The differences and quantity of secondary metabolites of medicinal plant could be the cause of differences in the biological activity of these plant extracts (Ghasemzadeh et al., 2016). From $\mathrm{IC}_{50}$ values using per cent DPPH free radical scavenging activity, it was observed that amongst solvents, the mean value of $\mathrm{IC}_{50}(\mu \mathrm{g} / \mathrm{ml})$ of methanol extract was found to be lowest (1291), followed by ethanol (1304), aqueous (1308) and acetone (1331).

Spectrophotometric quantification of total antioxidant capacity through the formation of Phosphomolybdenum complex was performed to evaluate the total antioxidant potential amongst the experimental samples. Total antioxidant capacity (TAC) of the fruits extracts of Triphala and its fruit constituents: Amla, Bahera and Harad in various solvents (aqueous, methanol, ethanol and acetone) were evaluated. Antioxidants present in the sample reduce the Mo (VI) to Mo (V), which then react with the phosphate group of sodium phosphate to form a green colored Mo (V)-phosphate complex (phosphomolybdenum complex) in an acidic medium. 
This complex is then spectrophotometrically measured at $\chi_{\max }$ The reaction is highly time dependent. DPPH free radical scavenging activity and total antioxidant capacity of fruits extracts (acetone, ethanolic, methanolic and aqueous) of Triphala powder and its fruit constituents: Amla, Bahera and Harad exhibited wide variation and showed concentration/dosage dependence.

Amongst samples, Bahera (1198) has lowest mean value of $\mathrm{IC}_{50}$, followed by Amla (1325), Harad (1374) and Triphala powder (1381). Thus, the total antioxidant potential estimation follows the order as follows: Bahera $>$ Amla $>$ Harad $>$ Triphala powder. Antioxidant activity of samples may be suspected of containing the compound capable of donating proton to the free radicals (Fidrianny et al., 2015). Flavonoids and phenols were the compounds capable of donating proton to the free radicals. Besides that, cinamic acid and benzoic acid was compound capable donating proton on free radicals
(Fidrianny et al., 2010; Heim et al., 2002). The region could lead to a significant difference both in the content of bioactive compounds and their bioactivities. DPPH (\%) and TAC (\%) values are strictly dependent on polyphenolics content TAC (\%) and TPC followed the same order. These data are in accordance with that of other authors who have shown that high total polyphenolics content increases antioxidant function and that there is a positive correlation between polyphenolics content and antioxidant function. From $\mathrm{IC}_{50}$ values using per cent total antioxidant capacity, it was observed that amongst solvents, the mean value of $\mathrm{IC}_{50}(\mu \mathrm{g} / \mathrm{ml})$ of aqueous extract was found to be lowest (1288), followed by methanol (1298), ethanol (1337) and acetone (1429). Amongst samples, Amla (1269) has lowest mean value of $\mathrm{IC}_{50}$, followed by Triphala powder (1297), Bahera (1347) and Harad (1440). Thus, the total antioxidant potential estimation follows the order as follows: Amla $>$ Triphala powder $>$ Bahera $>$ Harad.

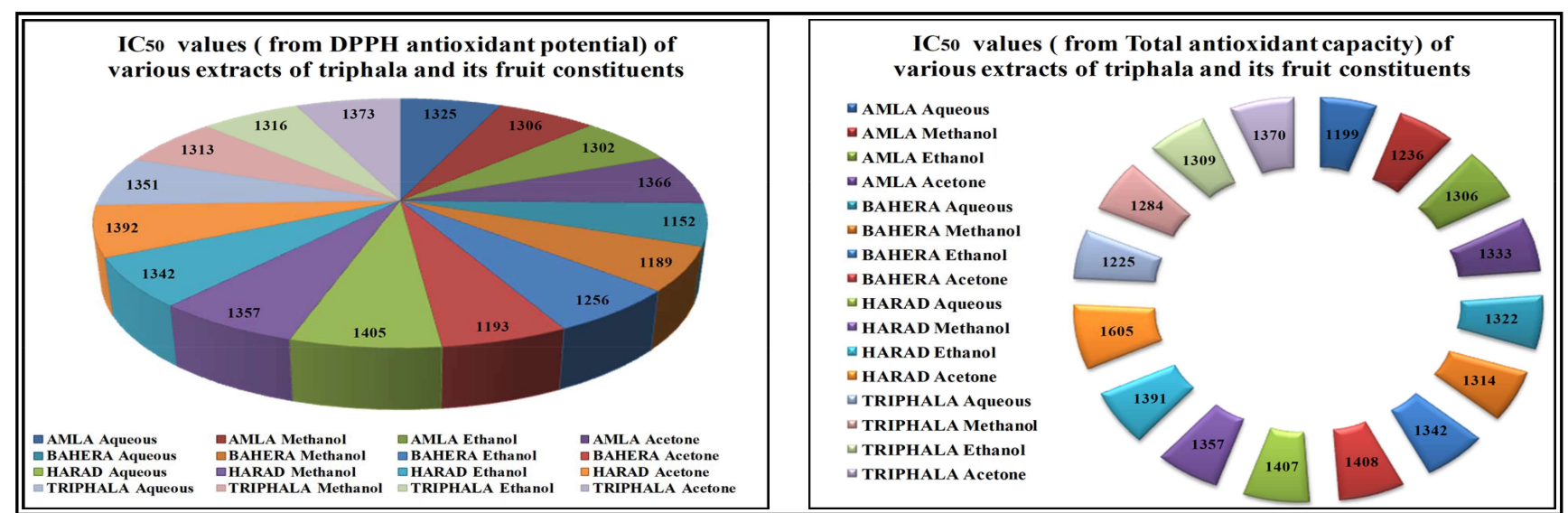

Figure 8: $\mathrm{A} . \mathrm{IC}_{50}$ values of various extracts of Triphala and its fruit constituents from DPPH Free radical scavenging activity. B. Total antioxidant capacity.

\section{Pharmacognostic studies of Triphala powder and its fruits constituents}

Anand et al. (1997), Khan and Gilani (2008), Biradar et al. (2008), Sharma et al. (2015), cited the information on pharmacological activities of $T$. belerica which are antioxidant, antimicrobial, antidiarrheal, anticancer, antihypertensive, hepatoprotective, antipyretic, etc., Jain and Mahajan (2015) studied the antimicrobial activity of aqueous extract of triphala powder and its constituents against $P$. aeruginasa, E. coli, B. subtilis, K. pneumoniae and $S$. aureus by cup-plate method. Triphala was found strongly bactericidal against $P$. aeruginosa. $T$. chebula showed maximum inhibitory zone against the same pathogen, followed by E. coli and other two Gram positive bacteria. T. belerica, however showed maximum inhibitory activity against $B$. subtilis.

According to Kaur et al. (2002) and Jagetia et al. (2002), Triphala is used in popular traditional medicine for the treatment of many chronic diseases such as ageing, heart ailments, hepatic diseases, etc. Meher et al. (2018) observed the pharmacological activities of the medicinal plant $T$. chebula, viz, antioxidant and free radical scavenging activity, antibacterial activity, antifungal activity, antiviral activity, antiprotozoal activity, anti-inflammatory and antiarthritic activity. Elizabeth (2005) conducted the antimicrobial activity of Bahera against 9 human microbial pathogens. The aqueous extract of dry fruit at $4 \mathrm{mg}$ concentration showed highest zone of inhibition against S.aureus. Alam et al. (2011) also postulated that the crude methanolic extract of the fruits of T. belerica along with its various organic fractions elicited both in vitro and in vivo antioxidant activity as well as antibacterial activity. Hasan et al. (2016) summarized that E. officinalis have diverse pharmacological activities like antimicrobial, antioxidant, anti-inflammatory, radioprotective, hepatoprotective, antitissuive, and many other activities. This medicinal plant is also reported to have anticancer, antidiabetic, antidepressant, antiulcerogenic, wound healing activities and so forth. Tripathi et al. (2016) screened the dried fruit extracts of Triphala powder constituents for secondary metabolites and also determined their antimicrobial activity in various fruit extracts of E. officinalis, T. belerica and T. chebula in different solvents against the pathogenic bacterial strains. The maximal zone of inhibition was found in ME fruit extracts towards the examined bacterial strains. Among these, highest microbial inhibition was recorded against $S$. typhi (24.0) and E. faecalis (23.5) with T. chebula and $E$. officinalis fruit extracts, respectively.

Triphala is an Indian traditional herbal formulation composed of E. officinalis, T. belerica and T. chebula in the ratio of $3: 2: 1$. Amongst these natural therapeutic agents, Amla showed the highest antibacterial activity followed by Triphala powder, 
Bahera and Harad. In case of antifungal activity, it was Bahera which showed the highest activity against the test organisms ( $A$. niger, A. flavus and C. albicans) followed by Amla, Harad and Triphala powder.

Trends in proximate composition

\begin{tabular}{|l|l|}
\hline Parameter & Order \\
\hline Moisture $(\%)$ & Amla $>$ Bahera $>$ Harad (Seeds $>$ Aerial parts $>$ Roots) \\
\hline Crude Fat $(\%)$ & Bahera $>$ Harad $>$ Amla (Seeds $>$ Aerial parts $>$ Roots) \\
\hline Ash $(\%)$ & Bahera $>$ Amla $>$ Harad (Seeds $>$ Roots $>$ Aerial parts) \\
\hline Crude Protein $(\%)$ & Harad $>$ Bahera $>$ Amla (Seeds $>$ Aerial parts $>$ Roots) \\
\hline Crude Fibre $(\%)$ & Harad $>$ Bahera $>$ Amla $($ Roots $>$ Aerial parts $>$ Seeds) \\
\hline $\begin{array}{l}\text { Total } \\
\text { Carbohydrates }(\%)\end{array}$ & Harad $>$ Amla $>$ Bahera $($ Seeds $>$ Aerial parts $>$ Roots) \\
\hline
\end{tabular}

Trends in minerals composition

\begin{tabular}{|l|l|}
\hline Minerals composition & Order \\
\hline Fe content $(\mathrm{ppm})$ & Bahera $>$ Amla $>$ Harad \\
\hline $\mathrm{Cu}$ Content $(\mathrm{ppm})$ & Harad $>$ Bahera $>$ Amla \\
\hline $\mathrm{Zn}$ Content $(\mathrm{ppm})$ & Amla $>$ Bahera $>$ Harad \\
\hline Mn Content $(\mathrm{ppm})$ & Amla $>$ Bahera $>$ Harad \\
\hline
\end{tabular}

The use of these compounds as therapeutic agents will open a chapter of cheaper and safe herbal substitute of antibiotics and may prove as a tool to check the problem of increasing antimicrobial resistance in pathogens.

Trends in phenolics and flavonoids contents in different parts of Triphala constituents

\begin{tabular}{|l|l|}
\hline Parameters & Order \\
\hline $\begin{array}{l}\text { Total Phenolics } \\
\text { Content }(\mathrm{mg} \mathrm{GAE} / \mathrm{g})\end{array}$ & Harad $>$ Amla $>$ Bahera (Aerial parts $>$ Roots) \\
\hline $\begin{array}{l}\text { Total Flavonoids } \\
\text { Content }(\mathrm{mg} \mathrm{CE} / \mathrm{g})\end{array}$ & Harad $>$ Bahera $>$ Amla (Aerial parts $>$ Roots) \\
\hline
\end{tabular}

Trends in phenolics and flavonoids contents in promising extracts of Triphala and its fruit constituents

\begin{tabular}{|l|l|}
\hline Parameters & Order \\
\hline $\begin{array}{l}\text { Total Phenolics } \\
\text { Content }(\mathrm{mg} \mathrm{GAE} / \mathrm{g})\end{array}$ & $\begin{array}{l}\text { Amla }>\text { Triphala }>\text { Bahera }>\text { Harad } \\
(\text { Aqueous }>\text { Methanol }>\text { Ethanol }>\text { Acetone })\end{array}$ \\
\hline $\begin{array}{l}\text { Total Flavonoids } \\
\text { Content }(\mathrm{mg} \mathrm{CE} / \mathrm{g})\end{array}$ & $\begin{array}{l}\text { Bahera }>\text { Triphala }>\text { Amla }>\text { Harad } \\
(\text { Methanol }>\text { Acetone }>\text { Aqueous }>\text { Ethanol })\end{array}$ \\
\hline
\end{tabular}

Trends in extract yield (g/100 g) of promising extracts of Amla, Bahera and Harad along with Triphala

\begin{tabular}{|l|l|}
\hline Parameters & Order \\
\hline $\begin{array}{l}\text { Extract yield } \\
(\mathrm{g} / 100 \mathrm{~g})\end{array}$ & $\begin{array}{l}\text { Harad }>\text { Triphala }>\text { Amla }>\text { Bahera } \\
(\text { Aqueous }>\text { Methanol }>\text { Ethanol }>\text { Acetone })\end{array}$ \\
\hline
\end{tabular}

Trends in total antioxidant potential using various available methods

\begin{tabular}{|l|l|l|}
\hline Parameters & Fruits/Solvents & Order \\
\hline $\begin{array}{l}\text { \%DPPH Free Radical } \\
\text { Scavenging Activity }\end{array}$ & $\begin{array}{l}\text { Amongst fruits } \\
\text { Amongst solvent }\end{array}$ & $\begin{array}{l}\text { Bahera }>\text { Amla }>\text { Harad }>\text { Triphala } \\
\text { Methanol }>\text { Ethanol }>\text { Aqueous }>\text { Acetone }\end{array}$ \\
\hline $\begin{array}{l}\text { Capacity } \\
\text { Catal Antioxidant }\end{array}$ & $\begin{array}{l}\text { Amongst fruits } \\
\text { Amongst solvent }\end{array}$ & $\begin{array}{l}\text { Amla }>\text { Triphala }>\text { Bahera }>\text { Harad } \\
\text { Methanol }>\text { Ethanol }>\text { Aqueous }>\text { Acetone }\end{array}$ \\
\hline $\begin{array}{l}\mathrm{IC}_{50}(\mu \mathrm{g} / \mathrm{ml}) \\
\mathrm{IC}_{50}(\mu \mathrm{g} / \mathrm{ml}) \\
\text { from } \% \mathrm{TAC}\end{array}$ & $\begin{array}{l}\text { Amongst fruits } \\
\text { Amongst solvent }\end{array}$ & $\begin{array}{l}\text { Amongst fruits } \\
\text { Amongst solvent }<\text { Amla }<\text { Harad }<\text { Triphala }\end{array}$ \\
\hline
\end{tabular}

\section{Conclusion}

From the present studies, these attributes supports that aqueous fruit extracts of E. officinalis, T. chebula and T. belerica could serve as a potential antioxidant and antimicrobial constituents. The bioactive components responsible for their antioxidant and antimicrobial activity could be used as reducing agents and capping agents in the synthesis of metallic/bimetallic nanoparticles. The results obtained may be helpful rationale to formulate these fruit extract in modern system of health care directly or indirectly.

\section{Acknowledgments}

We would like to thank CSIR, New Delhi for funding and supporting this research and IIT Delhi for providing the necessary facilities during the experimental investigation.

\section{Conflict of interest}

The authors declare that there are no conflicts of interest in the course of conducting the research. All the authors had final decision regarding the manuscript and decision to submit the findings for publication.

\section{References}

Temple, N.J. (2000). Antioxidants and disease: More questions than answers. Nutrition Research, 20(3):449-459.

Willett, W.C. (2002). Balancing life-style and genomics research for disease prevention. Science, 296(5568):695-698.

Yanai, N.; Shiotani, S.; Hagiwara, S.; Nabetani, H. and Nakajima, M. (2008). Antioxidant combination inhibits reactive oxygen species mediated damage. Bioscience, Biotechnology, and Biochemistry, 72(12):3100-3106. 
Ablise, M.; Mao, X.M. and Kasim, R. (2011). Antioxidant activities of Uyghur medicinal tea in human HL-60 cell line and rat hepatic microsomes. Journal of Medicinal Plants Research, 5:2677-2268.

Vijayabaskar, P. and Shiyamala, V. (2012). Antioxidant properties of seaweed polyphenol from Turbinaria ornata (Turner) J. Agardh. Asian Pacific Journal of Tropical Biomedicine, 2(1):90-98.

Ito, N.; Fukushima, S. and Tsuda, H. (1985). Carcinogenicity and modification of the carcinogenic response by BHA, BHT, and other antioxidants. CRC Critical Reviews in Toxicology, 15(2):109-150.

Vundać, V.; Rantner, A. and Lazibat, M. (2007). Content of polyphenolic constituents and antioxidant activity of some Stachys taxa. Food Chemistry, 104(3):1277-1281.

Wei, A. and Shibamoto, T. (2007). Antioxidant activities and volatile constituents of various essential oils. Journal of Agricultural and Food Chemistry, 55(5):1737-1742.

Siddique, N.A.; Mujeeb, M.; Najmi, A.K. and Akram, M. (2010). Evaluation of antioxidant activity, quantitative estimation of phenols and flavonoids in different parts of Aegle marmelos. African Journal of Plant Science, 4(1): 1-5.

Parcheta, S.V.; Paliwal, R. and Sharma, S. (2011). Preliminary phytochemica screening and in vitro antioxidant potential of hydro-ethanolic extract of Euphorbia neriifolia Linn. International Journal of PharmTech Research, 3(1):124-132.

Kuo, P.C.; Cherng, C.Y.; Jeng, J.F.; Damu, A.G.; Teng, C.M.; Lee, E.J. and Wu, T.S. (2005). Isolation of a natural antioxidant, dehydrozingerone from Zingiber officinale and synthesis of its analogues for recognition of effective antioxidant and antityrosinase agents. Archives of Pharmacal Research, 28(5):518-528.

Kochhar, A.; Nagi, M. and Sachdeva, R. (2006). Proximate composition, available carbohydrates, dietary fibre and anti nutritional factors of selected traditional medicinal plants. Journal of Human Ecology, 19(3):195-199.

Pandey, M.; Abidi, A.B.; Singh, S. and Singh, R.P. (2006). Nutritional evaluation of leafy vegetable paratha. Journal of Human Ecology, 19(2):155-156.

Taiga, A.; Suleiman, M.N.; Aina, D.O.; Sule, W.F. and Alege, G.O. (2008) Proximate analysis of some dry season vegetables in Anyigba, Kogi State, Nigeria. African Journal of Biotechnology, 7(10):1588-1590.

Nordeide, M.B.; Hatløy, A.; Følling, M.; Lied, E. and Oshaug, A. (1996). Nutrien composition and nutritional importance of green leaves and wild food resources in an agricultural district, Koutiala, in southern Mali. International Journal of Food Sciences and Nutrition, 47(6): $455-468$.

Kutbay, H.G. and Tolga, O.K. (2001). Foliar N and P resorption and nutrient levels along an elevational gradient in Zelkova carpinifolia (Pall.) C. Koch subsp. yomraensis Ansin and Gercek. Annals of Agri Bio Research, 6(1):1-8.

Odebunmi, E.O.; Oluwaniyi, O.O.; Awolola, G.V. and Adediji, O.D. (2009) Proximate and nutritional composition of kola nut (Cola nitida), bitter cola (Garcinia cola) and alligator pepper (Afromomum melegueta). African Journal of Biotechnology, 8(2):308-310.

Patterson, E. (1996). Standardized extracts: Herbal medicine of the future. Herb Market Rev., 2:37-38.

Cook, N.C. and Samman, S. (1996). Flavonoids-chemistry, metabolism, cardioprotective effects, and dietary sources. The Journal of Nutritional Biochemistry, 7(2):66-76.
Lotito, S.B.; and Frei, B. (2006). Consumption of flavonoid-rich foods and increased plasma antioxidant capacity in humans: cause, consequence, or epiphenomenon? Free Radical Biology and Medicine, 41(12): $1727-1746$

Shan, B.; Cai, Y.Z.; Sun, M. and Corke, H. (2005). Antioxidant capacity of 26 spice extracts and characterization of their phenolic constituents. Journal of Agricultural and Food chemistry, 53(20):7749-7759.

Wong, P.Y.Y. and Kitts, D.D. (2003). Chemistry of buttermilk solid antioxidant activity. Journal of Dairy Science, 86(5):1541-1547.

Chang, C.L. and Lin, C.S. (2012). Phytochemical composition, antioxidant activity, and neuroprotective effect of Terminalia chebula Retzius extracts. Evidence-Based Complementary and Alternative Medicine, pp:125247. doi:10.1155/2012/125247.

Gökmen, V.; Serpen, A. and Fogliano, V. (2009). Direct measurement of the total antioxidant capacity of foods: the 'QUENC ER' approach. Trends in Food Science and Technology, 20(6-7):278-288.

Prasad, N.K.; Yang, B.; Zhao, M.; Wang, B.S.; Chen, F. and Jiang, Y. (2009) Effects of high pressure treatment on the extraction yield, phenolic content and antioxidant activity of litchi (Litchi chinensis Sonn.) fruit pericarp. International Journal of Food Science and Technology, 44(5):960-966.

Ngamkitidechakul, C.; Jaijoy, K.; Hansakul, P.; Soonthornchaeonnon, N. and Sireeratawong, S. (2010). Antitumor effects of Phyllanthus emblica L.: Induction of cancer cell apoptosis and Inhibition of in vivo tumour promotion and in vitro invasion of human cancer cells. Phytotherapy Research, 24(9):1405-1413.

Ghasemzadeh, A.; Jaafar, H.Z.; Ashkani, S.; Rahmat, A.; Juraimi, A. S.; Puteh, A. and Mohamed, M.T.M. (2016). Variation in secondary metabolite production as well as antioxidant and antibacterial activities of Zingiber zerumbet (L.) at different stages of growth. BMC Complementary and Alternative Medicine, 16(1):104.

Ghasemzadeh, A.; Nasiri, A.; Jaafar, H.Z.; Baghdadi, A. and Ahmad, I. (2014). Changes in phytochemical synthesis, chalcone synthase activity and pharmaceutical qualities of Sabah snake grass (Clinacanthus nutans L.) in relation to plant age. Molecules, 19(11):1763217648 .

Wang, S.Y.; Bunce, J.A. and Maas, J.L. (2003). Elevated carbon dioxide increases contents of antioxidant compounds in field-grown strawberries. Journal of Agricultural and Food Chemistry, 51(15): 4315-4320.

Dumas, Y.; Dadomo, M.; Di Lucca, G. and Grolier, P. (2003). Effects of environmental factors and agricultural techniques on antioxidantcontent of tomatoes. Journal of the Science of Food and Agriculture, 83(5):369-382.

Anand, K.K.; Singh, B.; Saxena, A.K.; Chandan, B.K.; Gupta, V.N. and Bhardwaj, V. (1997). 3,4,5-trihydroxy benzoic acid (gallic acid), the hepatoprotective principle in the fruits of Terminalia belericabioassay guided activity. Pharmacological Research, 36(4):315-321.

Khan, A.U. and Gilani, A.H. (2008). Pharmacodynamic evaluation of Terminalia bellerica for its antihypertensive effect. Journal of Food and Drug Analysis, 16(3):6-14.

Biradar, Y.S.; Jagatap, S.; Khandelwal, K.R. and Singhania, S.S. (2008). Exploring of antimicrobial activity of Triphala Mashi: An ayurvedic formulation. Complementary and Alternative Medicine, 5(1): 107-113 
Sharma, K.R.; Kalauni, S.K.; Awale, S. and Pokharel, Y.R. (2015). In vitro free radical scavenging activity of methanol extracts of some selected medicinal plants of Nepal. Austin Journal of Biotechnology and Bioengineering, 2:1-5.

Jain, S. and Mahajan, D. (2015). Antimicrobial analysis of Triphala and comparison with its individual constituents. Indian Journal of Pharmaceutical and Biological Research, 3(3):55-60.

Jagetia, G.C.; Baliga, M.S.; Malagi, K.J. and Kamath, M.S. (2002). The evaluation of the radioprotective effect of Triphala (an ayurvedic rejuvenating drug) in the mice exposed to $\gamma$-radiation. Phytomedicine, 9(2):99-108.

Kaur, S.; Arora, S.; Kaur, K. and Kumar, S. (2002). The in vitro antimutagenic activity of Triphala: An Indian herbal drug. Food and Chemical Toxicology, 40(4):527-534.

Meher, S.K.; Panda, P.; Das, B.; Bhuyan, G.C. and Rath, K.K. (2018) Pharmacological profile of Terminalia chebula Retz. and Willd. (Haritaki) in Ayurveda with evidences. Research journal of Pharmacology and Pharmacodynamics, 10(3):115-124.

Elizabeth, K.M. (2005). Antimicrobial activity of Terminalia bellerica Indian Journal of Clinical Biochemistry, 20(2):150-153.

Alam, M.B.; Zahan, R.; Hasan, M.; Khan, M.M.; Rahman, M.S.; Chowdhury, N.S. and Haque, M.E. (2011). Antioxidant, antimicrobial and toxicity studies of the different fractions of fruits of Terminalia belerica Roxb. Global Journal of Pharmacology, 5(1):7-17.

Hasan, M.R.; Islam, M.N. and Islam, M.R. (2016). Phytochemistry, pharmacological activities and traditional uses of Emblica officinalis: A review. International Current Pharmaceutical Journal, 5(2): 14-21.
Tripathi, S.; Anuradha, J.; Mishra, S. and Kumar, S. (2016). In vitro antioxidant and antimicrobial efficacy of Triphala constituents: Emblica officinalis, Terminalia belerica and Terminalia chebula. Journal of Pharmacognosy and Phytochemistry, 5(6):273-277.

Buenz, E.J.; Schnepple, D.J.; Bauer, B.A.; Elkin, P.L.; Riddle, J.M. and Motley, T.J. (2004). Techniques: Bioprospecting historical herbal texts by hunting for new leads in old tomes. Trends in Pharmacological Sciences, 25:494-498.

Park, E.J. and Pezzutto, J.M. (2002). Botanicals in cancer chemoprevention. Cancer and Metastasis Reviews, 21:231-255.

Devasagayam, T.P.A. and Sainis, K.B. (2002). Immune system and antioxidants, especially those derived from Indian medicinal plants. Indian Journal of Experimental Biology, 40:639-655.

Govindarajan, R.; Vijayakumar, M. and Pushpangadan, P. (2005). Antioxidant approach to disease management and the role of 'Rasayana' herbs of Ayurveda. Journal of Ethnopharmacology, 99:165-178.

Hammer, K.A.; Carson, C.F. and Riley, T.V. (1999). Antimicrobial activity of essential oils and other plant extracts. J. Appl. Microbiol., 86(6): 985

Shoib A. Baba and Shahid A. Malik (2015). Determination of total phenolic and flavonoid content, antimicrobial and antioxidant activity of a root extract of Arisaema jacquemontii Blume. Journal of Taibah University for Science, 9(4):449-454.

Voon, H.C.; Bhat, R. and Gulam, R. (2012). Flower extracts and their essential oils as potential antimicrobial agents. Comprehensive Reviews in Food Science and Food Safety, 11:34-55.

Citation Tamanna Malik, V. K. Madan and Ram Prakash (2020). Herbs that heal: Floristic boon to the natural healthcare system. Ann. Phytomed., 9(2):6-14. http://dx.doi.org/10.21276/ap.2020.9.2.2 